\title{
COERÇÃO EM KANT E SCHELLING. FUNDAMENTAÇÃO E CONSEQÜÊNCIAS'
}

\author{
Leonardo Alves Vieira**
}

SWNTESE - Tomando como ponto de partida a discussão sobre a coerção em Kant e Schelling, tenho a intenção de explicar como eles provam a possibilidade da liberdade em conexảo com a coerçẫo. Comparando ambas teorias da liberdade e da coerçấo, duas formas diferentes de conceber o Direito e a Moralidade serão identificadas. De acordo com Kant, as leis juridicas săo leis morais ou leis da liberdade, de tal forma que há uma mediaçăo entre Direito e Moralidade. Scheling se opce radicalmente ao pensamento de Kant. O Direito tem seus próprios principios de conhecimento e ele não depende de imperativos morais. Por um lado, esta oposiçä́o caracteriza uma controvérsia dentro do próprio Idealismo alemảo, entre Hegel, que concorda com a tese kantiana, e Fichte, que segue a concepção schellinguiana. Por outro lado, esta discussão não esté limitada à flosofia kantiana ou ao Idealismo alemlio. Lançando măo do legado kantiano, Habermas critica a interpretaçăo weberiana do poder legitimo nas sociedades ocidentais modernas. De acordo com Weber, o poder nestas scciedades está baseado na tacionalidade interna e formal do Direito. Ao contrário, Habermas tem a intençăo de mostrar que a idéia do estado democrático deve sua legitimidade à ligaçlo entre Direlto e Moral.
ABSTRACT - Kant and Schelling on coercion. Theory and consequences. Starting from a discussion on Kant's and Schelling's theory of coercion, I intend to explain how they prove the possibility of freedom in connection with coercion. By comparing both theories of freedom and coercion, two different forms of conceiving right and morality will be identified. According to Kant, the legal laws are moral laws or laws of freedom, so that there is a mediation between right and morality. Scheling radically opposes Kant's thought. Right has its own principles of knowledge and it does not depend on moral imperatives. On the one hand, this opposition characterizes a controversy within the German Idealism itself, between Hegel, who follows Kant's view, and Fichte, who agrees with Schelling's thesis. On the other hand, this discussion is not confined within bounds of Kant's philosophy and German Idealism. By making use of Kant's legacy, Habermas criticizes the Weberian interpretation of legitimated power in the modern western societies. According to Weber, the power in these societies is based on the internal and formal rationality of right. On the contrary, Habermas intends to show that the idea of the democratic state owes its legitimacy to a link between right and morality.

- As questőes abordadas neste trabalho foram primeiramente discutidas na mesa redonda: "Avaliação da concepçăo kantiana do Direito e da Moral, na perspectiva de Hegel, Habermas, Sartre e Macintyre", no "VII Encontro Nacional de Fllosofia da ANPOF", realizado em Águas de Lindóia, no período de 19 a 24 de cutubro de 1996, Uma parte das questōes abordadas aquí foi objeto de um artigo, apresentado no "Simpósio Internacional sobre a Justiça em Kant, Habermas e Rawls", reallzado em Florianópolis no periodo de 18 a 22 de agosto de 1997. Este artigo, intitulado "Direito e justiça em Kant e Schelling. Uma controvérsia paradigmática", bem como os artigcs do referido simpósio serăo publicados no livro "Estudos em politica 2: A teoria da justiça de J. Rawls e suas interlocuçbes", pela EDUFSC.

** Universidade Federal de Minas Gerais - UnMG. Pesquisador do Conselho Nacional de Desenvolvimento Cientifico e Tecnológico - CNPq.

\begin{tabular}{|l|l|l|l|l|l|}
\hline VERTTAS & Porto Alegre & v. 43 & $n^{2} 4$ & Dezembro 1998 & p. $843-871$ \\
\hline
\end{tabular}


KBY WORDS - Freedom, coercion, right, morality, democratic state.

A questão da coerção (Zwang) constitui um problema para aquelas teorias, como as de Kant e Schelling, que procuram fundamentar a liberdade. Ela surge justamente no momento em que se trata de pensar a autonomia e aquilo que ameaça destrui-la, a saber, a coerção. O filósofo, portanto, se defronta com a tarefa de justificar a coerção e a sua coexistência com a liberdade do arbitrio ou da vontade. Não é por acaso, então, que, no contexto de filosofias que buscam uma legitimaçẫo da liberdade, a questão básica a ser resolvida pode ser assim formulada: como a liberdade pode ser afirmada e confirmada diante da coerçăo?

As posições teóricas de Kant e Schelling se identificam justamente no fato de que ambas abordam a questăo da coerção dentro do âmbito maior da questăo da liberdade. Para além das diferenças que ressaltam nestas teorias, o núcleo comum consiste em lidar com a coerçăo a partir de sua fonte. Assim sendo, no estudo desta questão em ambos filósofos, tomarei como marco referencial, no caso de Kant, a incondicionalidade da liberdade e as chamadas "leis morais ou da liberdade" - formando a primeira parte (I) deste trabalho, intitulada "autonomia e coerçăo" - e, no caso de Schelling, o "problema da filosofia moral" - constituindo a segunda parte (II), intitulada "o Direito Natural tomado ao pé da letra".

O cotejo entre Kant e Schelling no tocante à questão da coerção nos mostrará, a principio, teses antagônicas, uma vez que, como veremos, o exercicio da coerção acaba por resultar na destruição do próprio Direito Natural, segundo os pressupostos da filosofia schellinguiana. Em virtude disto, Schelling tentará, na sequiência de sua reflexăo filosófica, evitar este resultado, na medida em que a coerção será reexaminada a partir de uma outra perspectiva. Neste segundo momento, no qual a questão da coerção não é mais tematizada de acordo com os parâmetros do "problema da filosofia moral", mas segundo a oposição entre a lei moral e um impulso visando o próprio proveito (eigennütziger Trieb) ${ }^{2}-\mathrm{e}$, portanto, ainda dentro do contexto maior da fundamentação da liberdade -, a coerção não significará a destruição do Direito Natural, mas o modo próprio de atuação do aparato jurídico. Embora, nesta segunda fase, haja aparentemente uma certa identidade entre as teses defendidas por Kant e Schelling, as diferenças ainda săo bastante relevantes, de tal forma que "a reavaliação da coerção" - terceira parte (III) do trabalho - levada a efeito por Schelling implica na admissăo de certos pressupostos, os quais, no entanto, não podem mais se coadunar com as teses kantianas.

Por fim, pretendo mostrar - quarta parte (IV), intitulada "Consequiências do confronto entre Kant e Schelling" -, em um primeiro momento, que as teses antagônicas defendidas por Kant e Schelling espelham uma divisåo teórica dentro do próprio Idealismo alemão, a saber, entre Hegel e Fichte, no tocante à interpretaçāo

1 Kant, Metaphysik der Sitten, Rechtslehre, B 6s; Kritik der reinen Vernunft, B,560s; Schelling, Neue Deduktion des Naturrechts, \$ 71.

2 Schelling, System des transzendentalen Idealismus, 576. 
do Direito e da Moral. Em um segundo momento, pretendo referir que um certo problema do debate entre Kant e Schelling acerca da coerção - a saber, o problema de uma mediação entre Direito e Moral - problema este também desenvolvido nas obras de Hegel e Fichte pertinentes a esta temática, é retomado na crítica de Habermas a Weber, tendo em vista, por parte de Habermas, encontrar critérios adequados ao mundo pós-moderno para a formaçâo da vontade e a construção de um estado de direito democrático.

\section{1 - Autonomia e coerçäo}

Tendo em vista a incondicionalidade da liberdade, a justificação da coerção e as leis morais ou da liberdade, a saber, as leis éticas e as leis juridicas, o problema - no qual está implícito o pressuposto, segundo o qual a ação empírica e condicionada do ser humano é exteriorização de sua liberdade incondicionada - com o qual Kant se defronta consiste em determinar a preservaçăo da liberdade, cuja fonte é incondicional, diante da facticidade do empirico. ${ }^{3}$

Já na Crítica da Razão Pura (1781), na qual trata-se de determinar os critérios da necessidade e da universalidade rigorosa, capazes de fornecer as condiçōes indispensáveis para um discurso cientifico sobre o mundo fenomênico, ${ }^{4}$ Kant distingue a causalidade operando segundo a necessidade da natureza e a causalidade operando a partir da liberdade (aus Freiheit). ${ }^{5}$ Enquanto a primeira causalidade diz respeito à "ligação de um estado com um estado anterior no mundo sensivel", de tal forma que a) aquele estado suceda a este de acordo com uma regra e b) aquele estado anterior - o estado condicionante --, por sua vez, seja empiricamente condicionado, a segunda causalidade, porém, é entendida como uma "faculdade de iniciar por si mesma um estado", sem que a causa de um tal estado seja, por sua vez, novamente empiricamente condicionada.

Uma tal distinção, salienta Kant, só é possivel com base em uma outra distinçã̃o, a saber, entre fenômenos e coisas em si, sem a qual "a liberdade não pode ser salva". ${ }^{6}$ Pois, se, por um lado, esta causa inteligivel ou noumenal - a causalidade a partir da liberdade - não está contida na série dos fenômenos e não é por esta determinada, por outro lado, no entanto, os efeitos desta causa são determinados por outros fenômenos. ${ }^{7} \mathrm{O}$ efeito, portanto, pode ser considerado livre, se se tem em mente a sua causa inteligivel ou noumenal. Todavia, ele pode ser também considerado como ocorrendo de acordo com a necessidade da natureza, caso seja encarado exclusivamente como um acontecer a partir dos próprios fenômenos.

Esta causalidade a partir da liberdade é "a idéia transcendental da liberdade, sobre a qual o conceito prático da liberdade se fundamenta" ${ }^{8}$ Pois embora o nosso arbitrio seja afetado por móveis sensiveis, sendo, desse modo, um arbitrium sensi-

3 Bartuschat, Zur Deduktion des Rechts aus der Vernunft bei Kant und Fichte, 179; Kant, Metaphysik der Sitten, Rechtslohre, B 6.

Kant, Kritik der reinen Vernunit, B 4.

Ibidem, B 560 f.

Ibidem, B 564 .

Ibidem, B 565 .

Ibidem, 8561 . 
tivum, ele é, ao mesmo tempo, um "arbitrium sensitivum liberum", de tal forma que o ser humano pode dar ínício a uma nova ação, sobrepondo-se a uma coaçāo (Nötigung) procedente de móveis sensiveis. ${ }^{9}$

Em virtude deste modo de atuar próprio da causalidade a partir da liberdade, a Crítica da Razão Pura, em um primeiro momento, considerando a demonstração realizada nela da possibilidade de uma causalidade a partir da liberdade juntamente com a causalidade conforme às leis da natureza, e a Critica da Razăo Prática (1788) procuram justificar e fundamentar criticamente a incondicionalidade da liberdade. ${ }^{10} \mathrm{Em}$ um segundo momento, a saber, segundo 0 aspecto doutrinário, Doutrina do Direito e Doutrina da Virtude, respectivamente primeira e segunda partes de A Metafisica dos Costumes (1797), são tematizados elementos materiais não mais dedutíveịs do princípio incondicional da liberdade, já que ela tem por objeto investigar como o efeito daquela causa inteligivel se impöe, enquanto expressão da incondicionalidade da liberdade, na esfera tanto do que é contingente quanto do que é necessário, segundo as leis da natureza. ${ }^{11}$

A legitimidade da coerção, portanto, é explicada sob a perspectiva desta incondicionalidade da liberdade. Em primeiro lugar, a coerçăo, ${ }^{12}$ interpretada como um "impedimento" (Hindernis) ou "resistência" (Widerstand) à liberdade, é ela mesma resultado de um "certo uso da liberdade mesma" (ein gewisser Gebrauch der Freiheit selbst). ${ }^{13}$ Assim sendo, a coerção é um efeito livre de uma causalidade incondicionada. Todavia, embora sendo livre e exteriorização de um princípio incondicional, ela impede o exercício da liberdade em seu proceder segundo uma lei universal e se opōe, portanto, ao principio universal do Direito, o qual exige a convivência entre os arbítrios baseada em uma lei universal. Este obstáculo efetivado pela coerçăo assinala um estado de injustiça (Unrecht), justamente porque ela nega o estipulado pelo princípio universal do Direito. ${ }^{14}$ Neste sentido, a coerção é a negação da universalidade do Direito, acarretando com isto o exercício deficiente da liberdade do arbítrio.

A coerção enquanto efeito invibializador da convivência de seres autônomos, os quais regulam esta convivência justamente através da universalidade da lei, faz com que as exteriorizaçōes dos individuos autônomos - os efeitos livres de suas

9 Ibidem, B 562.

10 Na perspectiva kantiana, esta incondicionalidade da liberdade não pode ser esclarecida através da

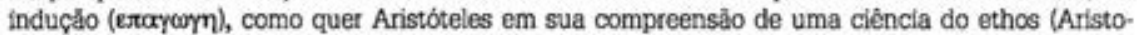
telis. Ethica Nicomachea, A, VII, 1098 b 3), já que a induçăo nos fornece, segundo Kant, apenas uma universalidade empirica (empirische Allgemeinheit).(Kant. Kritik der reinen Vernunft, B 4). A perspectiva indutivista, partindo do singular para o universal (Kant. Kritik der reinen Vernunft, B 3s; Aristóteles. Analytica posteriora, B, 19, 100 a3 - 100 b5), acabaria por nos conduzir a tomar o ser humano tal como ele é, como se ele, assim compreendido, fosse o ser humano tal como ele deve ser (Sollen) ou segundo a idéia da humanidade (Idee der Menscheit). (Kant. Metaphysik der Sitten, Tugendlehre, A 45).

11 Sobre a diferença entre critica e doutrina em Kant v. Bartuschat, Zur Deduktion des Rechts aus der Vernunft bef Kant und Fichte, $176 \mathrm{~s}$.

12 Como meio para realizar a coerçăo atua a força (Gewalt). V. Köhler, Zur Begründung des Rechtszwangs im Anschluss an Kant und Fichte, 99.

13 Kant, Metaphysik der Sitten, Rechtslehre, B 35.

14 Ibidem, B 34. 
causas inteligiveis - sejam submetidas à causalidade da série empirica e fenomênica. Em virtude disto, estes indivíduos passam a ser tratados unilateralmente segundo apenas a sua dimensão fenomênica.

Esta unilateralidade exige, em segundo lugar, um outro uso da liberdade, atuando como uma oposição àquele primeiro uso. A segunda coerçăo exercida contra a primeira, operando como uma resistência à resistência à liberdade segundo leis universais, repõe novamente as exteriorizaçōes dos seres autônomos, na medida em que elas são interpretadas como os efeitos livres de uma causa inteligivel. A coerção, oposta a um obstáculo à liberdade, segundo leis universais, - portanto, a segunda coerção contra a primeira coerção - atua no mundo fenomenal como aquilo que preserva as açōes dos seres humanos, enquanto expressőes livres de um principio incondicional. Assim sendo, a segunda coerçăo desfaz a injustiça promovida pela primeira e restabelece as normas legais da justiça inicialmente feridas.

Em ambos os casos, na coerção viabilizadora e na coerção invibializadora da convivência de indivíduos segundo leis universais, são pressupostas tanto a liberdade do coator quanto a do coagido. No caso do coator - seja do coator que é um impecilho para a realização da liberdade segundo leis universais, seja o coator que repöe esta liberdade -, como admite o próprio Kant, a ação fenomênica por ele engendrada é fruto do princípio incondicional da liberdade, o qual, por sua vez, situa-se para além da série condicionada dos fenômenos. Mas, também no caso do coagido - seja do coagido enquanto objeto de uma coerção obstacularizadora da liberdade segundo leis universais, seja do coagido enquanto objeto da coerção que, oposta à primeira, é compatível com a liberdade segundo leis universais -, a coerção não destrói a sua liberdade, visto que ele encontra-se limitado não na causa noumenal da liberdade, mas no efeito desta, na exteriorização advinda ou que possa advir desta causa.

Se, primeiro, a lei jurídica é uma lei moral ou lei da liberdade e se, segundo, a coerçăo, exercida contra a coerção oposta, por sua vez, à liberdade segundo leis universais, é ela mesma compativel com esta liberdade, então o próprio sistema juridico pode ser interpretado por Kant como "a lei de uma coerção reciproca, concordando necessariamente com a liberdade de cada um, sob o principio da liberdade universal". ${ }^{15}$ Este aparato legal de mútuo controle, "segundo a analogia da possibilidade de movimentos livres de corpos, sob a lei da igualdade da ação $\mathrm{e}$ da reação", estabelece as condições, segundo as quais as exterionizações da causalidade noumenal são interpretadas como efetivação da liberdade no mundo fenomenal e não como simples produtos de uma causalidade empiricamente condicionada.

A exemplificação đisto é identificável na articulaçăo oferecida por Kant entre o estado de natureza (status naturae, Naturzustand) e a sociedade civil (bürgerliche Gesellschaft, status civilis). ${ }^{16}$ Nesta articulação são ressaltados, ao meu ver, três importantes elementos: 1) o estado de direito (rechtlicher Zustand), 2) a justiça (Gerechtigkeit) e 3) a coerção (Zwang).

15 Ibidem, B 36 s.

16 Kant, Metaphysik der Sitten, Rechtslehre, B 154ss; B 191ss. 
Relativamente ao estado de natureza, a afirmação básica de Kant é a de que ele não é um estado de direito (nicht-rechtlicher Zustand). Isto não significa que, pelo menos aos olhos de Kant, năo haja, no estado de natureza, sociedades baseadas em um aparato legal (como p. ex., a sociedade conjugal) ou que não haja aquisições em geral via contratos. A descaracterizaçăo do estado de natureza enquanto um estado de direito fundamenta-se em dois pontos: a) o estado de direito oferece as condiçōes para que cada indivíduo torne-se um partícipe daquillo é seu direito e b) o estado de direito estabelece as condições formais de uma justiça pública (öffentliche Gerechtigkeit). Com o termo justiça pública Kant quer dar a entender a justiça distributiva (austeilende ou distributive Gerechtigkeit; lex iustitia), a qual assegura a cada indivíduo aquilo que, de fato, lhe pertence, diante de outros quaisquer individuos que queiram se apropriar indevidamente daquilo que ele possui.

Ora, o estado de natureza não preenche estas duas condições. Como no estado de natureza os individuos se encontram segundo o grau de sua respectiva força e violência (Gewalt, violentia), não há propriamente uma instância superior capaz de dirimir os conflitos e exercer a justiça distributiva, quanto o direito se torna controverso (ius controversum). Neste sentido, o estado de natureza não é propriamente um estado de injustiça, mas fundamentalmente um estado privado do Direto (Rechtlosigkeit, status iustitia vacuus). No estado de natureza faltam condiçöes para a promoção da justiça, estando os indivíduos entregues à sua própria força fisica.

Em virtude disto, é, por um lado, injusto querer permanecer em um estado que não é de direito e não apreșenta condições favoráveis para a implementação da justiça, bem como, por outro lado, é um dever - e não simplesmente um ato astuto de sobrevivência - abandonar uma tal situação, a qual, em virtude de sua própria natureza, exige a passagem de um estado tão inseguro para a sociedade civil promotora da "coerção externa publicamente legal" (... einen öffentlich gesetzlichen äusseren Zwang ...) e, consequentemente, da justiça distributiva. A coerção a qual cada indivíduo encontra-se submetido no estado de natureza, visto que cada um é vulnerável à força e violência de outros indivíduos, restando a cada um o recurso à sua própria força fisica, é, por sua vez, obstaculizada por esta coerção externa publicamente legal, a qual restabelece o princípio universal do Direito, cuja efetivação da justiça apenas o estado de direito pode levar a bom termo.

A coerçăo em Kant, no entanto, não se limita apenas ao âmbito do sistema jurídico, onde domina a coerção externa, mas estende-se também à esfera das leis éticas, nas quais tem lugar a autocoerção. ${ }^{17} \mathrm{O}$ prefixo "auto" (selbst) significa que a coerção nắo é exercida por um outro (seja um indivíduo, seja uma instituição) como no caso do sistema juridico -, mas no, pelo e contra o próprio indivíduo.

No entanto, embora exercida pelo próprio indivíduo, a autocoerção é também uma coerçäo oposta a uma primeira coerção, já que há, como admite o próprio Kant, "uma coação (Nötigung) via móveis da sensibilidade", diante da qual "a liberdade no entendimento prático" ou a "liberdade do arbitrio" se afirma como a "independência do arbítrio" deste tipo de coação ${ }^{18}$ A determinação do arbítrio

17 Kant, Metaphysik der Sitten, Tugendlehre, A 2 e 9.

18 Kant, Kritik der reinen Vernunft, B 562; Kant, Metaphysik der Sitten, Rechtslehre, B 5 s. 
ocorrendo independentemente de móveis provenientes da sensibilidade é o "conceito negativo da liberdade do arbítrio", visto que, neste caso, uma determinação do arbítrio procedente das inclinaçōes (Neigungen) e de todo móvel sensivel (jeder sinnliche Antrieb) é bloqueada ou negada. Kant denomina de efeito negativo aquilo que a lei moral, neste caso especifico, opỏe à coerçằo proveniente da sensibilidade. Ora, como Kant qualifica o sentimento (Gefühl) como a base das inclinações e móveis sensiveis, então este efeito negativo é também um sentimento e, de fato, o sentimento de dor (Schmerz). ${ }^{19} \dot{\mathrm{E}}$ justamente a dor proveniente do fato de que as inclinações não conseguiram efetuar a determinação do arbítrio, justamente porque elas foram negadas enquanto fatores determinantes dele. A dor configura um represamento das inclinações, somente na medida em que elas são contrárias à lei moral e determinam o arbitrio. ${ }^{20}$

O "conceito positivo do arbítrio" exige, portanto, um ir além da produção deste sentimento de dor. Em um primeiro momento, na Doutrina do Direito, Kant faz uma abordagem bastante abstrata deste conceito positivo, qualificando-o como a "faculdade da razảo pura de ser prática para si mesma". ${ }^{21}$ Em seguida, na Doutrina da Virtude, há uma especificação desta primeira qualificação: “... posto que as inclinações sensiveis induzem a fins ... que podem ser contrários à obrigação, então a razão legisladora não pode combater sua inflụênçia, a não ser, por sua vez, através de um fim moral oposto, o qual, portanto, tem de ser dado a priori independentemente da inclinaçăo".22

Com efeito, percebemos aqui uma semelhança na argumentação kantiana, na medida em que o fim moral é oposto a um fim proveniente de inclinações sensiveis e, desta forma, tornando o arbítrio independente da coerção exercida por estas inclinações, enquanto estas se apresentam como instância máxima e suprema de determinação do arbítrio, assim como, analogamente, no caso do sentimento de đor, a determinação do arbítrio através das inclinaçōes é bloqueada. Todavia, diferentemente do sentimento de dor, não há apenas um represamento destas inclinações, mas a oferta de um fim moral a priori capaz de determinar positivamente 0 arbítrio, e não apenas evitar a sua determinaçăo através delas.

Em virtude disto, a coerção - entendida como aquilo que se opōe a uma primeira coerçăo e, ao mesmo tempo, é compativel com a liberdade segundo leis universais - estabelece, seja de forma positiva (como no caso da coerção externa, dirigida contra uma primeira coerçāo, e da autocoerção, enquanto fim moral oposto a um fim proveniente das inclinaçōes sensiveis), seja de forma negativa

19 Kant, Kritik der praktischen Vernunft, A 128 s.

20 Já que os seres humanos são "seres naturais racionais" (vernüntige Naturwesen) (Kant, Metaphysik der Sitten, Tugendlehre, A 2), nāo há, entăo, uma açło humana que ocorra sem inclinaçāo. Neste sentido, toda açäo humana é uma açăo com inclinação (Handlung mit Neigung), sendo que a açăo moralmente reprovável é justamente aquela motivada pela inclinaçăo (Handlung aus Neigung). Posto que, entāo, a inclinaçấo inevitavelmente acompanhará o efeito fenomènico produzido pela causa inteligivel, a proprla inclinação - mas uma tal "dirigida e guiada pela lel moral"- pode também atuar como um elemento coatcr contra aqueies móveis sensiveis coatores e opostos à lei moral. Contudo, a incilnaçāo "dirigida e guiada pela lei moral" nåo fol tematizada por Kant. V. Strangas, Kritik der Kantischen Rechtsphilosophie, 32-38.

22 Kant, Metaphysik der Sitten, Rechtslehre, B 6.

Kant, Metaphysik der Sitten, Tugendlehre, A 6. 
(como no caso da autocoerção enquanto sentimento de dor), as condições indíspensáveis para que o fenômeno produzido pela causa noumenal seja considerado como "fenômeno livre" ou sua expressão na esfera empírica. Desta forma, Ética e Direito tematizam, através da coerção e autocoerção, a efetivação fenomênica da causa inteligivel.

\section{2 - O Direito Natural tomado ao pé da letra}

Em seu artigo, Nova Dedução do Direito Natural, publicado no Jornal Filosófico de uma Sociedade de Eruditos Alemães em $1796,{ }^{23}$ o começo da argumentação de Schelling apresenta um tom nitidamente kantiano. Também Schelling reconhece a diferença entre um ser em si (Wesen an sich), agindo através de uma causalidade da liberdade (Causalität der Freiheit), ao qual compete a autonomia, e o fenômeno (Erscheinung) ${ }^{24}$ Este é "tudo aquilo que pode ser objeto" e, portanto, é heteronômico. Movido por um grande pathos, ele exorta no § 3 ao indivíduo para cessar de ser fenômeno e esforçar-se por tornar-se um ser em si. "Esta é a suprema exigência de toda filosofia prática".

Esta causalidade, na medida em que ela domina o mundo dos objetos ou dos fenômenos, a saber, o mundo da natureza, fazendo de todo o mundo "minha propriedade moral", justamente para poder exercer este poder sobre o mundo dos objetos, carece da mediação de uma causalidade física (physiche Causalität). Mas, como a causalidade da liberdade é autonomia, a causalidade física, enquanto medium de expressão da causalidade da liberdade, tem de ser, segundo seu principio, também autonomia..$^{25}$ Ora, uma tal causalidade congregando em si autonomia e heteronomia é a própria "vida", já que ela é "autonomia no fenômeno" ou "esquema da liberdade" - em uma clara alusão ao esquema transcendental enquanto mediação entre o inteligivel e o sensivel. ${ }^{28}$ Assim sendo, o individuo é interpretado - também aqui em um estilo semelhante ao de Kant, o qual, como dito acima, falava de um ser natural racional (vernünftiges Naturwesen) - como "ser vivo (lebendiges Wesen)", fazendo justiça tanto ao seu ser em si quanto ao seu ser fenomênico."7

Justamente porque é um ser vivo tal como apresentado acima, podem ser reconhecidas nele tanto uma liberdade incondicionada (unbedingte Freiheit) ou causalidade absoluta (absolute Causalität) quanto uma liberdade empírica (empirische Freiheit) ou causalidade empírica (empirische Causalität). ${ }^{28} \mathrm{O}$ caráter incondicionado ou absoluto da liberdade consiste no fato de que sua meta (Ziel) não é objetivamente ou empiricamente ou fenomenalmente determinada. Assumindo uma posição teórica que faz lembrar aquela de Fichte na Doutrina da Ciência

23 V. o relatório editorial da ediçẩo histórico-critica das obras de Schelling: Friedrich Wilhelm Joseph Schelling. Historisch-Kritische Ausgabe, Werke 3, p.115-135.

24 Schelling, Neue Deduktion des Naturrechts, $\$ \S 4,7$ e 8; mantenho a grafia da ediçăo por mim utilizada.

25 Ibidem, \$ 8.

${ }^{26}$ Kant, Kritik der reinen Vernunft, B 177.

27 Schelling, Neue Deduktion des Naturrechts, § 9.

28 Ibidem, $\$ \S 25,26$ e 27. 
(1794/95), ${ }^{29}$ Schelling defende a tese de que a causalidade da liberdade "esforça-se (streben) para realizá-la (a incondicionalidade) através de uma ação infinita". ${ }^{30}$ Mas, tendo em vista o fato de que esta incondicionalidade nāo é um ob-jeto, como algo que jaz empiricamente diante desta causalidade, então a realizaçăo empírica desta incondicionalidade nunca chegará ao seu termo, permanecendo sempre indefinida ou i-limitada.

No entanto, se a sua meta não é empírica ou objetiva, o esforço para realizá-la é empírico, já que o seu esforço em direção a esta meta ocorre "em uma série infinita de tempo". ${ }^{31}$ Justamente o fator "tempo" assinala uma năo-identidade ou uma multíplicidade (como "aquela dos objetos do mundo empirico"), a qual, por sua vez, traz consigo o elemento do conflito ${ }^{32}$ Pois, se, por um lado, "a causalidade absoluta nunca pode contradizer-se", 33 visto que, como acima dito, sua meta não é empiricamente determinada, por outro lado, uma limitação na liberdade justamente o que especifica a liberdade empírica - necessariamente terá que ocorrer, porque, em caso contrário, uma "atividade empiricamente llimitada" em um individuo provocaria uma "passividade empiricamente limitada em outro". E uma tal passividade, naturalmente, não poderia ser expressão empírica da causalidade incondicional da liberdade.

A argumentação de Schelling, portanto, tem por intenção demonstrar que a "autonomia do individuo" (Selbstheit des Individuums), exigida pela Moral, ${ }^{34}$ é efetivada no "conflito com outras causalidades", 35 portanto, na experiência da intersubjetividade. A limitação empírica que cada indivíduo está obrigado a realizar, com a finalidade de compatibilizar as vontades de todos os indivíduos ${ }^{36}$, traz à baila justamente o problema da universalidade (Allgemeinheit), da produção de uma unidade capaz de abrigar em si a multiplicidade. ${ }^{37}$ "O problema da filosofia moral", portanto, consiste na "uniăo da máxima individualidade com a máxima universalidade da vontade", perfazendo, desta forma, a "vontade absoluta". 38

Resolver este problema é a tarefa tanto da Ética quanto do Direito: "A Ética soluciona o problema da vontade absoluta através do fato de que ela torna idêntica a vontade individual com a vontade universal, e a Ciência do Direito através do fato de que ela torna idêntica a vontade universal com a vontade individual". 39 Assim sendo, a tarefa de ambos é providenciar o florescimento da intersubjetivi-

29 Fichte, Grundlage der gesamten Wissenschaftslehre, 101, 121 e 268 s.

30 Schelling, Neue Deduktion des Naturrechts, § 16.

31 Ibidem, § 17.

32. Ibidem, § 18,20 e 21.

33 Ibidem, $\$ 26$.

Ibidem, § 22. Esta experiência do confito ou da resistência oposta por outra(s) causalídade(s) à minha vontade é também responsável pela individuação moral.

37 Ibidem, \$ 41.

38 Ibidem, § 71 .

39 Ibidem, § 72. Não é minha intençâo explorar as diferenças estabelecicias por Schelling entre a esfera ética e a esfera furidica, mas apenas ressaltar o problema com o qual elas se defrontam e o contexto no qual surge o problema da coerção. Para uma análise mais detalhada destas esfera v. Hollerbach, Schellings Rechts- und Staatsbegnif in den Jahren 1796-1800, 307-324; Rivelaygue, Schelling et les apories du droit, 13-62; Vieira, Freiheit als Kultus, 256-265. 
dade de seres livres, propiciar condições empiricas para que aquela açāo infinita para realizar a incondicionalidade da liberdade possa, de fato, desenvolver-se. Esta é uma posição teórica análoga àquela de Kant, segundo a qual Ética e Direito lidam com o problema de como o fenômeno produzido pela causalidade noumenal pode ser considerado livre, ou seja, expressăo desta causalidade e não meramente um fenômeno ocorrendo segundo as leis da natureza.

É neste contexto que Schelling tematiza a coerção. Pois, todo individuo tem o direito de, através da ação, afirmar a autonomia de sua vontade e, consequientemente, opor-se a toda ação visando suprimir aquela autonomia ${ }^{40}$ Ora, a coerção se caracteriza por ser uma ação çue visa suprimir a autonomia ou forma da vontade (liberdade) de um indivíduo, na medida em que esta forma é condicionada pela matéria da vontade coatora. ${ }^{41}$ Portanto, o individuo é forçado a agir de acordo com o que é exigido pela ação do coator.

Como o individuo tem o direito de afirmar a autonomia de sua vontade contra qualquer vontade que queira suprimi-la, então este direito se transforma, por sua vez, em um direito à coerçăo, ${ }^{42}$ i. e. o direito possuído por um indivíduo de exercer coerção contra todo individuo que queira suprimir a autonomia de sua vontade. No entanto, tanto a coerçäo pretendendo anular a autonomia do indivíduo, quanto a contracoerçăo, a qual o coagido tem direito, conduzẹm ao mesmo resultado, isto é, à neutralização daquilo que formalmente identifica todos os individuos, a saber, da liberdade da vontade, pois é justamente a matéria da vontade o que os diferen$\mathrm{cia}^{43} \mathrm{Em}$ virtude disto, a liberdade empirica deixaria de ser manifestaçăo da liberdade incondicionada, efeito livre de uma causa incondicional. Ora, no momento em que o traço de identidade entre eles é posto em questäo, cada indivíduo, o coator e o coagido, torna-se objeto ou fenômeno um para o outro. ${ }^{44}$ Neste sentido, eles não são mais encarados como seres vivos; tal como explicado acima, mas simplesmente seres naturais, os quais, justamente em virtude disto, são tratados segundo as leis da natureza. ${ }^{45}$

Com efeito, se eles são interpretados exclusivamente com base em sua dimensão natural, então o direito à coerção não pode mais ser encarado, segundo Schelling, como pertencendo ao âmbito de uma filosofia moral, mas à esfera de uma filosofia da natureza. O Direito Natural, portanto, năo significa mais um direito deduzido racionalmente, insito a todo ser livre e racional, mas, de acordo

40 Schelling, Neue Deduktion des Naturrechts, § 145.

41 Doidem, § 146 . O caso da coerção restrita meramente ao âmbito individual, por um lado, seria aquele, no qual aquilo que o individuo quer (a saber, a matéria da vontade) chegasse a determinar a autonomia da escolha do individuo (a forma da vontade).

Por outro lado, conforme salienta Schelling," ninguém pode ser coagido para açōes morais" (\$ 150), vale dizer, nínguém pode ser forçado a agir como um ser livre. Logo, "ccerçắo moral é uma contradiçäo". (§ 148) Diferentemente de Kant, no entanto, Schelling năo se pergunta, no contexto da Nova Deduçảo do Direito Natural, por uma autocoerçäo - o que, no entanto, ele fará mais tarde, como veremos. A razâo disto reside no fato de que ele a) considera a coerçẫo como pertecendo apenas à esfera do sistema jurídico ( $\$ \$ 150$ e 162) e b) qualifica a coerção apenas como coerçăo fisica (externa) e coerção psicológica (întema). (\$§ 147s).

Ibidem, § 150. 
com a acepção literal do termo "Direito Natural", o direito baseado na supremacia fisica (physische Úbermacht). ${ }^{46}$ Ele resulta ser, deste modo, o direito do naturalmente mais forte e mais capaz de impor a sua vontade.

Assim sendo, o direito à coerção, diferentemente da abordagem kantiana, não repõe a autonomia da vontade, mas, justamente ao contrário, torna inviável, tanto para o coagido quanto para o coator, cumprir aquela exigência suprema de toda filosofia prática, anunciada por Schelling, no início do texto, com um grande pathos: "cesse de ser fenômeno, esforce-se por tornar-se um ser em si". Também em virtude disto, o Direito, enquanto parte de uma filosofia moral, não pode mais resolver o problema da vontade absoluta, embora tal afirmação não seja explicitamente expressa no contexto da Nova Deduçăo do Direito Natural.

\section{3 - A reavaliação da coerção}

A dedução do Direito Natural proposta por Schelling tem como ponto final a sua própria destruição. No entanto, o texto não termina sem uma esperança de que o problema encontre, de alguma forma, uma soluçăo. No último parágrafo, Schelling reivindica uma nova ciência capaz de unificar, de um lado, o sistema jurídico com a força física, de outro.

Uma nova soluçāo para o problema pode ser considerada aquela apresentada na quarta parte do Sistema do Idealismo Transcendental (1800), intitulada "sistema da filosofia prática segundo os principios do idealismo transcendental". De acordo com estes princípios, o Eu enquanto agente, a saber, enquanto vontade, apresenta uma atividade objetiva, direcionada para algo externo diferente dela e uma atividade subjetiva, puramente ideal, tendo a vontade como o seu próprio objeto.

Uma outra diferença entre estas atividades expressa-se no modo como estas atividades se tornam objeto para o $\mathrm{Eu}$. $\mathrm{Na}$ atividade subjetiva, em nítida retomada da filosofia prática kantiana, o imperativo categórico ou a lei moral propicia a mediação, graças ao (à) qual os seres inteligentes podem querer "o puro autodeterminar", onde, portanto, a vontade quer a própria vontade ${ }^{47} \mathrm{Na}$ atividade objetiva, o impulso natural (Naturtrieb) exerce este papel intermediário, também designado na esfera moral como o impulso visando o próprio proveito (eigennütziger Trieb). ${ }^{48}$ Este impulso natural, surgindo por ocasião do agir do Eu no mundo externo, é a expressão fenomênica e empirica de uma causalidade denominada simplesmente impulso (Trieb). Este é aquele que transforma o objeto, tal como ele é, naquilo que ele deve ser. Năo por acaso, esta causalidade é interpretada por Schelling como a expressāo de uma atividade direcionada para o objeto externo. ${ }^{49}$ Ora, como a atividade deste Eu no mundo externo năo pode ter lugar sem uma mediaçăo material, então, no caso específico em questão, este mediação material para o Eu è o "corpo orgânico" (organischer Leib) ${ }^{50} \mathrm{O}$ impulso transformador de um objeto manifesta-se objetiva ou empiricamente, no caso do Eu agindo no mundo externo, como impulso natural de um corpo orgânico.

\footnotetext{
45 Ibidem, \$ 162.

47 Schelling, System des transzendentalen Idealismus, 574.

48 Ibidem, 575. 
A atividade subjetiva, direcionada para a autodeterminaçăo, se opōe à atividade objetiva, direcionada para um objeto extemo, o qual se denomina na Moral felicidade (Glückseligkeit). Enquanto uma preza a lei moral, a outra honra a vida feliz. A oposição entre ambas atividades, por sua vez, é responsável a) pelo fato de que o Eu tenha como objeto o "ato absoluto da vontade" e b) pelo fato de que o arbitrio seja a manifestação (Erscheinung) da vontade absoluta ${ }^{51}$

A rigor, a vontade absoluta não pode ser considerada nem livre nem não livire, visto que ela não pode desviar-se da autodeterminação. Todavia, caso ainda se insista no uso do termo "livre", então deve ser acrescentado o advérbio "absolutamente". A vontade absoluta é absolutamente livre, visto que ela age exclusivamente de acordo com " a necessidade interna de sua natureza", sem ter diante de si a possibilidade de "escolha entre opostos". ${ }^{52}$ É justamente o arbitrio que possui esta escolha, sendo, em virtude disto, identificado com "a liberdade propriamente dita ou aquilo que é comumente compreendido sob o nome de liberdade". 53

Como o próprio Schelling reconhece, ${ }^{54}$ uma tal distinção já fora feita antes por Kant. ${ }^{55}$ Porém, a ausência na filosofia kantiana de um método, "que não pressuponha nenhum fenômeno como dado", o impediu de entender adequadamente a relação entre vontade (absoluta) e arbítrio. Sendo o arbitrio manifestação ou expressão objetiva, fenomenal e empirica da vontade absoluta, ${ }^{56}$ Schelling pensa ter resolvido o problema da filosofia transcendental, a saber, se o Eu é também livre, enquanto é empírico. Como visto acima, o fenômeno pode ser entendido tanto como livre, na medida em que é o efeito da causa noumenal, quanto como um fenômeno ao lado de outros fenômenos, sujeito às leis da natureza. Ora, o arbitrio, aos olhos de Schelling, é precisamente o fenômeno livre, porque ele é a autonomia manifestada na condicionalidade, a atividade subjetiva objetivada.

Em virtude disto, o arbitrio, reunindo em si ambas atividades, evita os erros daqueles sistemas que investigam a liberdade: ou negar a liberdade, ao focalizar apenas a atividade objetiva; ou limitá-la à esfera da Razão pura, da pura autonomia, onde a) não há propriamente liberdade no sentido comum do termo, já que a atividade subjetiva nâo pode desviar-se de sua lei moral e onde b) a Razăo pura está aprisionada em um "quietismo sem fundamento", por não poder exercer uma efetiva oposição às açōes contrárias à sua lei moral. ${ }^{57}$

51 Ibidem, 575s. O termo "vontade absoluta" năo tem aqui o mesmo significado que ele detinha no texto de 1796 sobre o Direito Natural. Ibidem, 576.

53 Ibidem, 577.

54 Ibidem, 578.

55 Kant, Metaphysik der Sitten, Rechtslehre, B 26 s.

56 Schelling não fala mals de um "ser vivo", como no texto de 1796, acima abordado, mas de um "ser livre" (freles Wesen), que é ser racional e ser natural. (Schelling, System des transzendentalen Idealismus, 583) Todavia, a sua concepção do arbitrio ainda herda aquele "esquema da liberdade" enquanto "autonomia na manifestaçăo (Autonomie in der Erscheinung)". V. Schelling, Neue Deduktion des Naturrechts, $\$ 9$.

57 Schelling, System des transzendentalen Idealismus, 579. Bmbora, para Kant, como vimos, a Razăo năo se encontre neste quietismo, já que ela opōe o seu próprio fim ao fim proveniente da sensibilidade. 
Se uma tal concepção do arbitrio evitas estas unilateralidades, a questão da compatibilização entre as duas atividades ainda não foi resolvida. Com efeito, a atividade subjetiva, direcionada para a autodeterminação, por um lado, nāo pode suprimir o impulso natural, dado que este é responsável pela ação do Eu no mundo externo. Por outro lado, a atribuição ao arbitrio de cada um de poder limitar a manifestação objetiva da atividade subjetiva autodeterminante apresenta como resultado algo bastante precário, visto que o arbítrio se caracteriza por ser precisamente uma escolha entre opostos. Assim sendo, tal limitação pode ocorrer, como também não ocorrer. Logo, Schelling se vê obrigado a reavaliar o significado da coerção, já que justamente ela irá propiciar condiçōes para a convivência entre os arbitrios no mundo objetivo.

Em primeiro lugar, é importante entender o objeto, contra o qual a coerção é exercida. Ela năo será exercida sobre o arbítrio como um todo, i. e. atividade subjetiva e atividade objetiva, "já que nenhum ser racional lao qual se refere a atividade puramente ideal e subjetiva, adendo de LAV] pode ser coagido, mas apenas determinado a coagir a si mesmo". ${ }^{58}$ Neste sentido, a coerção não atinge a atividade subjetiva, a vontade pura, visto que esta age apenas em consonância com a sua autodeterminação, mas afeta apenas a atividade objetiva, a autonomia absoluta da vontade no seu exercício fenomenal. Assim sendo, a coerção sofrida pelo arbitrio no seu aspecto objetivo faz com que o agente, na qualidade de ser racional - já que o agente é ser racional (Vernunftwesen) e ser natural (Naturwesen) perceba a contradiçāo na qual ele se encontra e possa adequar sua ação às açōes de outros agentes, tendo em vista a convivência entre eles no mundo objetivo. Dessa forma, pode ser dito que a coerção exercida sobre o agente implica, em contrapartida, da parte deste mesmo agente, uma autocoerção.

Portanto, não sendo a atividade subjetiva, o objeto da coerção é, deste modo, o impulso natural visando o próprio proveito, uma vez que, pertencendo à esfera da atividade objetiva, este tem como objeto as suas vantagens singulares e, em virtude disto, pode inviabilizar aquilo que no texto sobre o Direito Natural foi denominado "uniăo da máxima individualidade com a máxima universalidade".

Em segundo lugar, o impulso natural tem de ser combatido com meios que sejam qualitativamente homogêneos ao próprio impulso. ${ }^{59}$ Este instrumento de combate qualitativamente homogêneo tem por tarefa "coagir este impulso a agir contra si mesmo" (contra o impulso mesmo), de tai forma que "o agente seja posto em contradição consigo mesmo".

Finalmente, em terceiro lugar, a coerção tem de ser posta pelo ser livre enquanto ser racional no mundo objetivo, "posto que ele lo mundo objetivo, adendo de LAV] se relaciona de forma totalmente inciferente com o atuar de seres livres como tais". ${ }^{61}$

\footnotetext{
58 Ibidem, 582.

59 Ibidem.

60 Bidem, $582 \mathrm{~s}$

61 Doidem, 583.
} 
Conforme a estas três condições, a coerção tem de pertencer ao âmbito da natureza (segunda condiçâo), opor-se ao impulso natural (primeira condição) e ser produzida pelo ser humano enquanto ser livre e racional (terceira condição).

Para Schelling, o sistema jurídico preenche estas três condiçōes, porque ele nunca poderá coagir a atividade subjetiva e puramente ideal e também pelo fato de que ele é um produto do ser livre. Apenas a segunda condição poderia gerar alguns problemas. No entanto, ele deixa bem claro que o sistema juridico ou, de acordo com a terminologia de Schelling, a "constituição jurídica" (Rechtsverfassung), é uma "segunda natureza", cujas leis, diferentemente da leis da primeira natureza - ou seja, as leis da "natureza sensível" em oposição às leis da "natureza legal" - têm por finalidade a efetivação da liberdade (zum Behuf der Freiheit). Ora, a constituição jurídica foi por ele comparada como uma máquina, preprogramada a atuar "automaticamente (von selbst), i. e., inteiramente às cegas, tão logo estes casos [= para os quais ela está preprogramada, adendo de LAV] sejam dados"; ${ }^{62}$ Ora, a coerção por ela exercida contra o impulso visando o proveito próprio deve ter lugar "de forma implacável e com a necessidade férrea, com a qual, na natureza sensivel, à causa sucede seu efeito". ${ }^{63}$

Assim sendo, aquilo que foi afirmado no fim do artigo sobre o Direito Natural é explicitado aqui. Se o Direito Natural se destrói, na medida em que ele se toma um direito à coerçăo, então ele não faz mais parte da esfera da filosofia moral. Se isto não foi explicitamente dito anteriormente, é aqui expresso de forma bem clara. "A Doutrina do Direito não é uma parte da Moral ou, em geral, uma ciência prática, mas uma ciência puramente teórica". ${ }^{84}$ Conseqüentemente, prossegue Schelling, "a ordem juridica não é uma ordem moral, mas uma ordem meramente natural", ${ }^{65}$ embora, como Schelling salienta, visando propiciar a realização da liberdade.

Esta reavaliação da coerção por parte de Schelling implica a radicalização de uma tese já defendida nos parágrafos finais do artigo sobre o Direito Natural. Lançando mão de uma terminologia proveniente de Aristóteles, o qual distingue o fazer ou atividade instrumental do agir ou práxis moral, o Direito, por conseguinte,

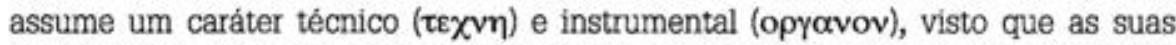
obras $(\varepsilon \rho \gamma \alpha)$ são, na verdade, fins $(\tau \varepsilon \lambda \eta)$ residindo para além das atividades ( $\pi \alpha \rho \alpha \tau \alpha \zeta \pi \rho \alpha \xi \varepsilon \iota \varsigma$ ) baseadas nas leis juridicas enquanto tais. ${ }^{66}$ Lançando mão da terminologia kantiana e schellinguiana, a concepção de Schelling pode ser assim resumida: o Direito, sendo produto no mundo objetivo do ser livre enquanto ser racional, é uma realizaçăo da razăo técnico-prática (technisch-praktische Vernunft), contrariamente à posição filosófica defendida por Kant, segundo a qual ele é a efetivação de uma razäo moral-prática (moralisch-praktische Vernunft). ${ }^{67}$

Além desta coerção levada a cabo pelo sistema juridico para viabilizar a convivência dos vários arbitrios no mundo objetivo, há uma outra coerçăo por ele

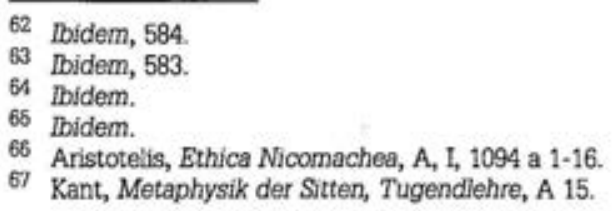


analisada, denominada coerçăo da natureza (Naturzwang). ${ }^{69} \mathrm{~A}$ ela, provocada "pela atividade de violência universalmente exercida" - em nitida alusão ao bellum omnium contra omnes de Hobbes - deve ser imputado o primeiro surgir de uma ordem jurídica. Foi justamente esta coerção da natureza, segundo Schelling, "que impeliu (getrieben) os seres humanos a deixar surgir uma tal ordem, sem que eles soubessem e de tal forma que eles foram surpreendentemente atingidos pelos primeiros efeitos de uma tal ordem". ${ }^{6}$ Assim sendo, Schelling se mostra totalmente contrário à tese de um contrato fundador, intencional e voluntariamente produzido, o qual conduz os seres humanos do estado de natureza para a esfera da sociedade política e, portanto, jurídica. A gênese da ordem jurídica não è obra do acaso (Zufall), nem também é o resultado de uma deliberaçâo racional a priori, mas é o fruto daquilo que ele também denominava "coerção das circunstâncias" (Zwang der Umstände). ${ }^{70}$ Premido e açoitado por situaçōes de conflito generalizado, os seres humanos se viram forçados a instituir uma ordem juridica capaz de resolver os seus conflitos mediante um procedimento menos desgastante e doloroso do que aquele da guerra. Sendo um aparato de coerção, o sistema juridico, em seu modus operandi, năo pode, portanto, negar a sua própria origem.

\section{4 - Conseqüências do confronto entre Kant e Schelling}

O cotejo entre as posiçōes teóricas de Kant e Schelling acerca da liberdade e da coerção aponta, de forma exemplar, para uma grande diferença, ao mesmo tempo em que ele serve, em um primeiro momento, tanto para compreender as teses de dois outros corifeus da filosofia alemã clássica, a saber, Fichte e Hegel, quanto para acompanhar o desdobramento desta problemática na discussăo hodierna travada entre Weber e Habermas.

Ao interpretar as leis éticas e jurídicas como leis morais ou da liberdade, Kant procurava, em primeiro lugar, ver nelas já a própria experiência da liberdade e, em segundo lugar, encontrar formas de mediação entre elas. São exemplos deste segundo momento o fato de que a) a obrigação jurídica pode ser assumida por uma obrigação de virtude, desde que năo haja mais nenhuma coerção externa impelindo a efetivação da obrigação jurídica, ${ }^{71}$ b) o "imperativo moral" é tanto a mediação pela qual conhecemos nossa liberdade, "da qual procedem todas leis morais e, por conseguinte, nossos direitos e deveres", quanto a mediação pela qual o conceito de Direito "pode ser desenvolvido", ${ }^{72}$ c) a formulação do "princípio universal do Direito" está calcada no imperativo categórico. ${ }^{73}$ Esta mediação, no entanto, le-

68 Schelling, System des transzendentalen Idealismus, 584.

69 Ibidem, 584s.

70 Ibjodem, 585. Uma outra abordagem da ccerção é a aquela que ocorre na histórla mundial. 0 conceito de historia abriga em si tanto liberdade quanto necessidade, necessidade “à qual o arbitrio mesmo está coagido a servir", arbitrio que, por sua vez, é "deusa da história".(Ibidem, 586 e 589). Segundo Schelling, há uma necessidade na histớria impelindo-a para a formação da "federaçalo de todos os estados", baseada em uma constituição juridica universal, à qual todos estados devem estar submetidos. (Didem, 586s).

73 Ibidem, B 33: Kant, Grundlegung zur Metaphysik der Sitten, B 52. 
vanta a questão a ser discutida mais adiante de saber se a leí jurídica é dedutivel da lei ética, tomando o Direito uma espécie de apêndice da Ética. Seja qual for a resposta, o que podemos constatar até o momento é a inserção do Direito e da Ética na dimensão da realização da liberdade. Neste sentido, a coerçāo, seja a interna, seja a externa, foi interpretada como uma re-ação a uma primeira ação coercitiva, a qual impossibilitava que o fenômeno fosse considerado como um fenômeno livre. A reação coercitiva, portanto, visava neutralizar obstáculos à efetivação do incondicionado no mundo fenomênico.

\section{$4.1-$ Hegel}

Apesar e para além das inúmeras diferenças, o próprio Hegel também se encontra dentro deste programa kantiano. Isto se evidencia, em primeiro lugar, na caracterizaçảo hegeliana das três esferas - Direito Abstrato, Moralidade e Eticidade - do Espirito Objetivo: "o ser-af́ (Dasein) de todas determinaçōes da liberdade" ${ }^{74}$ Torna-se patente, portanto, que elas constituem "o reino da liberdade realizada" enquanto "uma segunda natureza", ${ }^{5}$ mas não enquanto uma "natureza segunda e superior la constituiçāo juridica no sentido schellinguiano, como explicada acima], na qual domina uma lei da natureza ... uma lei da natureza tendo por finalidade a liberdade" ${ }^{76} \mathrm{~A}$ "segunda natureza", no sentido hegeliano, năo visa um telos alheio a ela, mas já é em si mesma a efetivação ou experiência da lei da liberdade ou moral.

Em segundo lugar, a estrutura dialética das Linhas Fundamentais da Filosofia do Direito (1821), começando com o Direito Abstrato, passando pela Moralidade e culminando na Eticidade, retoma a economia do texto da Metafisica dos Costumes - Doutrina do Direito e Doutrina da Virtude -, mas, ao mesmo tempo, acrescentando a esfera da Eticidade, com a qual Kant identificara a Moralidade.$^{\pi}$ Esta nova esfera é o resultado da dinâmica do movimento da vontade - segundo Hegel, negligenciada por Kant -, de acordo com a qual a Moralidade surge para superar uma deficiência do sistema jurídico e a Eticidade, por sua vez, soluciona aquilo que na Moralidade não podia mais ser solucionado. ${ }^{78} \mathrm{O}$ movimento dialético da vontade é construido de tal forma, que a esfera imediatamente subseqüente tem por tarefa solucionar a questăo que a esfera imediatamente anterior, em virtude de sua própria dinâmica interna, não é capaz de solucionar. Enquanto a Moralidade vem amparar o Direito Abstrato na efetivação da justiça - efetivação esta prejudicada pelo predominio da vontade individual sobre a vontade universal no caso do fenômeno da vingança -, a Eticidade, por sua vez, tem em vista a realizaçăo da justiça e do bem moral, os quais acabaram por ser negados, ao fim da esfera da Moralidade, pelas várias formal do mal. A Eticidade, portanto, enquanto negação đa negação, se propōe demonstrar a realidade efetiva da justiça e do bem moral na familia, na sociedade civil, no estado e na história mundial.

74 Hegel, Enzyklopädie der philosophischen Wissenschaften, § 486.

75 Hegel. Grundlinien der Philosophie des Rechts, \$ 4.

76 Schelling, System des transzendentalen Ideallismus, 583.

7 Kant, Metaphysik der Sitten, B 15.

$78 \mathrm{~V}$, Vieira, A herança kantiana na concepç̋̉o hegeliana do direito e da moral. 
Em terceiro lugar, tanto conforme às teses de Kant quanto conforme ao seu método dialético, Hegel considera a segunda coerção - aquela que visa restabelecer as condiçōes objetivas para o exercício da liberdade - exercida contra a primeira coerçăo, como "um suprassumir (Aufheben) de uma primeira coerção".79 Neste sentido, a primeira coerção significa a primeira negação do universal jurídi$\mathrm{co}$, sendo que ela, por sua vez, é necessariamente ${ }^{20}$ negada por uma segunda coerção, de tal forma que "o Direito se restabeleça através do negar esta sua negaçăo ... [e] se determine como efetivo e válido". ${ }^{81}$

Neste estilo da argumentação hegeliana, percebe-se, de um lado, a retomada da tese kantiana e simultaneamente, de outro lado, a sua inserçăo na dialética hegeliana. $\mathrm{O}$ sistema jurídico reafirma sua efetividade e legitimidade enquanto aparato de coaçāo, na justa medida em que ele se afirma mediante a negação (a segunda negação) daquilo que o negava (a primeira negação, a saber, a negaçăo da universalidade da justiça, negação esta cristalizada em suas várias formas), de tal forma que ele se apresenta, portanto, de acordo com o linguajar hegeliano, como a universalidade concreta, levada a cabo pela mediação do negativo. Interpretando a coerção sob a ótica da estrutura triádica do movimento dialético, Hegel procura mostrar a compatibilidade entre o ser-aí da liberdade e a experiência da coerção, assim como Kant, lançando mäo de outros principios teóricos, já havia também procurado articular estes dois momentos.

Ao contrário das teses de Kant e Hegel, todavia, Schelling leva a cabo no texto de 1796, primeiramente, uma espécie de reductio ad absurdum, na medida em que o Direito Natural se transforma em um direito exercido conforme às leis da natureza e, portanto, baseado na supremacia fisica. Posteriormente, no Sistema do Idealismo Transcendental, o Direito é exclúdo do âmbito da filosofia moral, interpretado como uma ciência teórica - figurativamente encarado como uma espécie de "mecânica" da liberdade - de tal forma que a ordem jurídica é encarada como uma ordem da natureza. Assim sendo, portanto, este aparato legal coator não é mais concebido como a vivência da liberdade, mas, segundo a expressão de Schelling, algo semelhante a uma máquina apropriada a produzir um telos que lhe é essencialmente estranho. Em virtude disto, e assumindo uma posição teórica contrária àquelas de Kant e Hegel, o Direito não apresenta nenhuma mediação interna com a Moral. Pelo contrário, qualquer aproximação entre ambas esferas é vista com suspeita e prejudicial à eficácia do aparato juridico.

\section{2 - Fichte}

A despeito de toda proximidade intelectual que Fichte pensa e quer ter com Kant, há uma profunda divergência entre ambos no que diz respeito à conceituação das leis jurídicas e éticas. ${ }^{82} \mathrm{~A}$ estratégia argumentativa de Fichte na Fundação do Direito Natural (1796) - referenciada apenas no texto de Kant A Paz Perpétua (1795), visto que a A Metafisica dos Costumes (1797) ainda não havia sido publi-

79 Hegel. Grundlinien der Philosophie des Rechts, § 93.

${ }^{80}$ Bbidem, 593.

8: Ibidem, \$ 82 .

82 Fichte, Grundlage des Naturrechts, Einleitung, III, $12 \mathrm{~s}$. 
cadia - consiste, em primeiro lugar, em afirmar que, levando-se em consideração apenas A Paz Perpétua, não fica claro se Kant deduz a lei jurídica da lei ética ou empreende uma outra forma de dedução. Em segundo lugar, Fichte procura aproximar as consideraçōes feitas por Kant acerca das leis de permissão (Erlaubnisgesetze, leges permissivae) com a conceituação do Direito desenvolvida por ele, com a intenção de demonstrar que ambos partilham de uma mesma posição teórica acerca do sistema jurídico.

Com relação ao primeiro ponto, as formulações de Kant deixam, de fato, margem à dúvida. Quando Kant, por um lado, na Crítica da Razão Pura, como visto acima, aborda a questão de uma causalidade a partir da liberdade, que é a idéia transcendental da liberdade, ele a qualifica como fundamento do conceito prático de liberdade. Ora, é evidente que o termo prático, tal como utilizado neste contexto, refere-se ao prático-moral enquanto contraposto ao prático-técnico, portanto de um imperativo categórico como contraposto a um imperativo hipotético. É neste sentido que, ao meu ver, devemos entender, portanto, a subdivisão das leis morais ou da liberdade em leis juridicas ou leis éticas, já que ambas leis expressam uma incondicionalidade a ser realizada na esfera fenoménica. Assim sendo, se quisermos ainda lançar mão do termo "deduzir", temos que falar de uma dedução tanto da lei ética quanto da lei jurídica a partir da lei moral ou da liberdade, ou seja, de uma lei que expressa categoricamente o que deve ser eticamente e juridicamente feito, portanto, de uma lei veiculadora de um dever-ser (Sollen). Como dito anteriormente, em Kant, leis éticas e juridicas trazem à luz este dever-ser incondicional, sendo que ambas leis exigem seja a coerção interna (leis éticas), seja a coerção externa (leis jurídicas).

No entanto, a dúvida de Fichte, por outro lado, acerca do fato de Kant ter deduzido ou não a lei jurídica a partir da lei ética é pertinente. De fato, e também como explicitado acima, o "imperativo moral" é tanto a mediaçăo pela qual conhecemos nossa liberdade, "da qual procedem todas leis morais e, por conseguinte, nossos direitos e deveres", quanto a mediação pela qual o conceito de Direito "pode ser desenvolvido". Uma formulaçăo como esta dificilmente deixa de suscitar a impressăo de que as leis jurídicas sảo deduzidas das leis éticas. Associado a isto temos a semelhança da formulação do princípio universal do Direito com o próprio imperativo categórico. Esta tese, porém, parece chocar-se com aquela reproduzida no parágrafo anterior, segundo a qual a idéia transcendental da liberdade é o fundamento do conceito prático de liberdade. Se este é o caso, então os conceitos do Direito e da Ética tem de ser deduzidos da idéia transcendental da liberdade e não da lei moral, bem como o próprio imperativo categórico torna-se inteligivel e, portanto, encontra sua fundamentação justamente nesta idéia.

O próprio Fichte soube reconhecer a importância, no conjunto da filosofia kantiana, da idéía transcendental da liberdade - "A liberdade é, segundo Kant, a faculdade de iniciar absolutamente (...) um estado" 83 -, qualificando-a de "excelente explicação nominal", embora simultaneamente 0 critique pelo fato de não têla deduzido do Eu absoluto - critica que era de se esperar de um filósofo-discípulo que procurava levar a filosofia do seu mestre à forma sistemática. Em virtude dis-

83 Fichte, System der Sittenlehre, § 2, 37. 
to, não é de se estranhar que também Fichte tenha inserido as leis jurídicas e éticas na dimensão da liberdade, assim como Kant. Afinal, o conceito de Direito tem como objeto "uma comunidade de seres livres como tais", 24 enquanto a lei ética "contém a determinação originária do ser livre" es5 sua autodeterminação absoluta.

Ora, se ambos reconhecem a extrema importåncia da idéia transcendental de liberdade, assim como, em consequêencia disto, tenham colocado a experiência ética e jurídica sob a égide da liberdade, então é o caso de se perguntar se, de fato, em Kant as leis juridicas têm sua base nas leis éticas.

Penso que uma explicação plausivel para esta divergência reside no duplo significado atribuido por Kant ao termo "lei moral" (moralisches Gesetz). Identifico, no minimo, dois significados deste termo. Por um lado, Kant o utiliza como o contraposto da lei de natureza, portanto, enquanto lei da liberdade, e, neste caso, ele engloba tanto as leis éticas (ethische Gesetze) quanto as leis jurídicas (juridische Gesetze). Bste é o significado empregado até o momento neste trabalho. Por outro lado, ele o toma como sinônimo de Sittengesetz, a "lei fundamental da Razão prática pura", a qual equivivale, de acordo com a terminologia empregada no primeiro significado, ao que ele denomina de leis éticas (ethische Gesetze). Assim sendo, lei moral pode restringir-se apenas à esfera ética ou moral (a lei moral estricto sensu) ou abranger o âmbito completo da lei da liberdade, a saber, os âmbitos ético e jurídico (a lei moral lato sensu). ${ }^{86}$

É legitimo também perguntar-se pelo motivo do emprego do termo "lei moral" neste duplo significado. $O$ motivo para tal reside justamente na identificação entre lei moral stricto sensu (a esfera prática no sentido estrito, a saber, a esfera ética) e causalidade mediante liberdade ${ }^{87}$ (a esfera do incondicionado). A intenção de Kant é mostrar que o nosso conhecimento imediato do prático-incondicionado é possivel graças à lei moral stricto sensu e, com base nisto, desenvolver sua reflexão sobre a esfera prática em sentido amplo, a saber, ético e jurídico.

Ao nível da Critica da Razão Pura foi demonstrada apenas a possibilidade de uma causalidade mediante liberdade como não sendo incompativel com a causalidade mediante leis da natureza. ${ }^{88} \mathrm{O}$ avanço da Crítica da Razão Prática no que diz respeito a esta questão em relação à Crítica da Razão Pura consiste em que aquilo que nesta era meramente uma possibilidade toma-se naquela uma realidade objetivo-prática justamente mediante a lei moral stricto sensu, a qual é o motivo imediato e incondicional de determinação do arbítrio ${ }^{89}$ Não por acaso, a lei moral stricto sensu, um princípio prático incondicionado, é a mediação que nos propor-

84 Fichte, Grundlage des Naturrechts, Binleitung, I, 9.

85 Fichte, System der Sittenlehre, \$ 3, 60.

86 Kant, Kritik der praktischen Vernunft, A 54 ss. Lei moral stricto sensu é também, ao meu ver, o significado de leis morais na passagem citada acima, de acordo com a qual as leís juridicas podem ser desenvolvidas a partir das leis morais ou éticas. V. Kant, Die Metaphysik der Sitten, Rechtslehre, B 47s.

87 "Das moralische Gesetz ist in der Tat ein Gesetz der Kausalität durch Freiheit" (A lei moral é, de fato, uma lei da causalidade mediante liberdade), v. Kant, Kant, Kritik der praktischen Vernunft, A 82.

${ }^{88}$ Kant, Kritik der reinen Vernunft, B 570 ss.

89 Kant, Kritik der praktischen Vernunft, A 83. 
ciona um conhecimento imediato do incondicionado na sua dimensâo prática lato sensu, ética e jurídica. ${ }^{\infty}$ Kant procura deixar claro que não é a liberdade o que imediatamente nos leva ao prático-incondicionado. Em primeiro lugar, o que se conhece imediatamente da liberdade é algo meramente negativo, a saber, a sua mera possibilidade e compatibilidade com a lei da natureza. Em segundo lugar, ela também não é algo imediatamente conhecido a partir da experiência, pois um tal conhecimento destrói a idéia mesma de uma causalidade incondicional. ${ }^{91}$ Portanto, o nosso conhecimento imediato do prático-incondicionado é viável mediante a lei moral. Ora, "a lei moral é [...] um imperativo, o qual ordena categoricamente, porque a lei é incondicionada". ${ }^{92}$

Esta formulaçăo da Crítica da Razão Prática nos ajuda a entender aquela formulação da Metafisica dos Costumes, segundo a qual "conhecemos nossa própria liberdade $[. .$.$] apenas mediante 0$ imperativo moral". ${ }^{93} \mathrm{Na}$ formulação posterior, o qualificativo do termo "imperativo", a saber, "moral", aparece como sinônimo do termo "categórico" na expressão "imperativo categórico". Esta sinonímia parece ser justamente o resultado da consideração da lei moral como um imperativo ordenando categoricamente, de tal forma que imperativo categórico ou moral manifesta a incondicionalidade prática.

A expressão "lei moral", enquanto imperativo categórico ou moral, é empregada no stricto sensu, embora ela possa ser o ponto de partida para a formulação do conceito de Direito. No contexto da Crítica da Razão Prática o caráter estrito e restrito à esfera ética do emprego da expressão "lei moral" pode ser identificado justamente naquilo que constitui uma das temáticas deste trabalho, a saber, a questão da coerção. Visto que o arbítrio humano pode oscilar entre a lef moral incondicional e motivos provenientes da esfera fenomênica - diferentemente de uma vontade santa, a qual está inevitavelmente submetida à lei moral - a relação entre este arbitrio e a lei moral é aquela de uma resistência da Razăo prática contra motivaçōes procedentes do âmbito sensivel. Ora, esta resistência é a coação interna ou inteligivel, a coaçăo moral. ${ }^{94}$ Ela é a coação exercida pela lei moral e negadora da negação da lei moral, repondo e reafirmando assim a incondicionalidade da liberdade. A coação moral é, portanto, a resistência oposta a uma resistência à lei moral. Ela é nada mais nada menos do que a autocoerção acima tematizada.

Na Metafisica dos Costumes, fala-se do imperativo moral como aquilo a partir do qual o conceito de Direito "pode ser desenvolvido". E, de fato, a formulação do princípio universal do Direito mostra o imperativo categórico ou moral atuando como base do desenvolvimento do conceito de Direito. Mas, isto significa que as leis jurídicas são deduzidas das leis éticas? Sim, caso se considere as leis éticas enquanto leis morais lato sensu. Nāo, caso se tome as leis éticas como leis morais stricto sensu.

\footnotetext{
90 Ibidem, A 525 .

91 Ibidem, A 53.

92 Ibider, A 57 ,

93 Kant, Metaphysik der Sitten, Rechtslehre, B 48.

9. Kant, Kritik der reinen Vermuft, A 57.
} 
De fato, as leis morais stricto sensu são impotentes para fundamentar o conceito de Direito, visto que o que este conceito exige, a saber, "a faculdade de obrigar outros", 95 não está ao seu alcance, porque elas podem no máximo oferecer uma coerção moral ou interna, i. e., a faculdade de obrigar a si mesmo, a autocoerção. As leis morais stricto sensu não estăo, além disso, em condiçōes de atuar naqueles três âmbitos nos quais se movem as leis jurídicas. Estas têm como objeto a) a relação externa que os individuos mantêm entre si; b) a relação entre arbitrios e c) a forma do arbitrio e năo a matéria do mesmo, a saber, aquilo que é o objeto do arbitrio. 96

A lei moral stricto sensu, no entanto, na medida em que ela configura o acesso imediato que nós, seres sensiveis e inteligiveis, temos ao incondicionado na sua figura prático-moral, torna-se a base das leis éticas e juridicas. Trata-se, portanto, das leis éticas e juridicas enquanto leis morais lato sensu. A nossa vivência primeira da liberdade é a coerção moral exercida pela lei moral, provocando uma resistência contra a resistência promovida pelos móveis sensiveis, e năo a coerção externa a nós mesmos que nos obriga a levar em conta em nossas açōes a lei universal. Ora, é justamente esta vivência primeira da liberdade, "a lei moral em mim" nos proporcionando "admiração" e "veneração", "7 na medida em que ela nos mostra a face prática da idéia transcendental da liberdade, que nos habilita a construir o conceito de Direito. Não é por acaso que o principio prático-jurídico incondicional é também interpretado como uma resistência reposta e oposta a uma resistência posta contra a universalidade das leis jurídicas. Ao se apresentar como aquilo que torna em realidade objetivo-prática o incondicionado, a lei moral stricto sensu expressa paradigmaticamente aquela incondicionalidade típica da vivência da liberdade, constituindo-se em uma espécie de referência ideal de como o incondicionado leva a cabo seu efeito no mundo fenomênico. Ora, este caráter paradigmático da lei moral stricto sensu a qualifica a ser uma lei moral lato sensu, já que este caráter paradigmático nos aponta para a incondicionalidade das leis éticas e juridicas.

Relativamente ao segundo ponto da argumentação de Fichte, a interpretação das leis juridicas enquanto essencialmente leis de permissão, a referência feita por ele diz respeito apenas a uma nota de pé de página ${ }^{98}$ No entanto, há uma outra nota de pé de página, na qual Kant volta a tratar destas leis, ${ }^{99}$ sem que a sua concepção básica de leis de permissão tenha sido alterada.

Como pertinentemente observa Bartuschat, a intenção de Kant não é caracterizar o Direito mediante as leis de permissão, mas inquirir acerca do sentido de se falar destas leis no contexto de leis práticas. ${ }^{100}$ A princípio, comenta Kant, parece existir uma contradição (Widerspruch) ao se falar de leis de permissão, já que lei implica uma "necessidade prática objetiva de certas ações", enquanto permissão

\footnotetext{
Kant, Motaphysik der Sitten, Rechtslehre, B 48.

Ibidem, B 31s.

97 Kant, Kritik der praktischen Vernunft, A 289.

96 V. Fichte, Grundlage des Naturrechts, Binleitung, II, 13;Kant, Zum ewigen Frieden, B 16 s.

9 Kant, Zurn ewigen Frieden, B 79.

100 Bartuschat, Zur Deduktion des Rechts aus der Vemunft bei Kant und Fichte, 174s.
} 
denota uma "contingência prática de certas ações". De um lado, a obrigaçâo (ou o dever-ser) exigida pela lei, de outro lado, a alternativa de realizar ou não ação (a permissão). Neste sentido, as leis de permissão apresentariam a coação (Nötigung) para uma ação - coação veiculada pela lei - mas uma coaçăo onde ninguém, de fato, pode ser coagido, visto que se trata de uma permissão.

Antes de abordar a soluçäo kantiana desta contradição, é importante analisar a consequêencia da identificaçăo das leis jurídicas com as leis de permissăo, como o fez Fichte. Ora, o resultado desta identificação é o deslocamento do Direito da esfera prático-moral (moral lato sensu), como em Kant, para a esfera práticotécnica. Se "a lei juridica apenas permite, mas nunca ordena que se exerça seu direito", ${ }^{101}$ então não há a este respeito nenhuma necessidade entre o pensamento de uma comunidade de seres livres exigida pelo conceito de Direito, de um lado, e a realização (Realisation) deste pensamento, ${ }^{102}$ de outro lado. De fato, este conceito responde apenas à pergunta pelo modo necessánio de construção da comunidade de seres livres. "Mas que uma tal comunidade deva (solle) ser erigida", isto escapa à conceituaçăo prático-técnica do Direito. Em virtude disto, as leis juridicas tais como interpretadas por Fichte não constituem mais um princípio prático incondicionado veiculador de um dever-ser. Elas são as condições técnicas necessárias para a constituiçăo de uma comunidade de seres livres, caso se queira erigir uma tal comunidade.

Voltando a Kant. As leis de permissão são contingentes ou, como Kant dirá mais tarde, provisórias, ${ }^{103}$ mas devem ser juridicamente reconhecidas. Nas duas notas de pé de página acima referidas esta tese é ilustrada, tomando como exemplo a posse de objetos e a constituiçăo de um país.

No caso da posse de objetos, Kant considera aquilo que foi adquirido no estado de natureza como posse suposta (possessio putativa), expressão traduzida para 0 alemão por Kant como posse honrada (ehrlicher Besitz). A posse de objetos ao nivel do estado de natureza é provisória e contingente, porque nele falta justamente a lei pública exercendo a justiça đistributiva, e, como conseqüência desta ausência, tornando esta posse precária e insegura. Esta posse, todavia, deve ser juridicamente reconhecida, pois, em caso contrário, a sociedade civil, bem como a própria obrigação de abandonar o estado de natureza perderiam sua razão de ser, visto que a sociedade civil possui aquelas condiçōes indispensáveis para exercer a justiça distributiva e efetivar "as leis sobre o meu e o teu", já presentes no estado de natureza, mas simultaneamente vulneráveis a todo tipo de violaçăo, sem, porém, a correspondente sanção jurídica competente para o estabelecimento da justiça. As leis de permissão devem ser juridicamente reconhecidas, porque o que nelas é precário, provisório e contingente receberá sua sançāo jurídica definitiva em uma condição civil suficientemente equipada para garantir a justiça.

O caráter provisório das leis de permissão no caso da constituição de um país mostra-se no fato de que uma constituição injusta ou com pouco grau de justiça é

101 Fichte, Grundlage des Naturrechts, \$4, Corollaria: 2), 54.

102 Ibidem, Einleitung, II, 9s.

${ }^{103}$ Kant, Metaphysik der Sitten, Rechtslehre, B 194. 
melhor do que a ausência de constituição. Tal constituição deve ser juridicamente permitida, na medida em que ela é passível-de reformas, de acordo com os critérios de uma constituição assegurando a efetivação da justiça distributiva. $\mathrm{O}$ juridicamente provisório e, portanto, permitido ganha seu título de direito, justamente na medida em que ele é o estágio antecedente daquele estágio de realizaçảo $\mathrm{e}$ efetivação do que no primeiro estágio era insuficiente e precário. $\mathrm{O}$ sentido das leis de permissão é facultar relações jurídicas contingentes e, neste sentido, ainda distantes do que é exigido pelo Direito promotor da justiça. Com efeito, elas antecipam na sua contingência e precariedade o que o efetivo estado de direito exige como uma norma incondicional.

Diferentemente de Schelling, o qual havia deslocado o Direito do âmbito prático-moral para o teórico, Fiche e Kant ainda o preservam na esfera prática. No entanto, o que ambos têm em mente com a esfera prática não é o mesmo. Enquanto Kant trabalha com o prátíco-moral, Fichte leva em conta o prático-técnico. E com a inserçâo do Direito na esfera prático-técnica, ele quer explicitamente impedir qualquer penetração de pressupostos éticos na racionalidade jurídica. Afinal, “a boa vontade não tem nada o que fazer no åmbito do Direito Natural. 0 Direito tem de deixar-se efetivar mediante a coaçăo (erzwingen), mesmo que nenhum ser humano possuisse uma boa vontade. E justamente a Ciêncla do Direito se dirige a projetar uma tal ordem de coisas. Neste terreno a força física, e ela apenas, confere ao Direito a sanção". ${ }^{104}$ Ora, a exclusão de elementos éticos do âmbito do Direito Natural tem lugar, justamente porque a convivência entre seres livres baseada exclusivamente em pressupostos éticos tais como lealdade (Treue) e confiança (Glaube) se mostrou insustentável, já que estes pressupostos são contingentes. Como não se trata de uma questâo de ter ou não boa vontade - portanto, de uma questão de moralidade -, o problema consiste em identificar condiçōes necessárias para uma tal convivência. Tais condiçōes são, aos olhos de F1chte, da ordem da legalidade, de tal forma que apenas "uma instância agindo com necessidade mecânica", a saber, a lei coercitiva, pode oferecer uma resistência àquelas ações contrárias ao universalmente admitido como de direito. ${ }^{105}$ Diferentemente de Hegel, para o qual a incapacidade do Direito de estabelecer a justiça a partir de sua dinâmica imanente faz surgir a esfera moral mediante a introdução de uma vontade que busque o universal enquanto tal, para Fichte justamente a incapacidade desta esfera moral de estabelecer as bases seguras da convivência entre seres livres exige como contrapartida a esfera jurídica. Neste sentido, o afastamento da boa vontade do âmbito do Direito Natural assegura ao sistema jurídico as condições indispensáveis para o bom desempenho de suas funções, enquanto $a$ introduçăo da moralidade na área da legalidade tornaria a convivência de seres livres inviável. Embora adotando estilos argumentativos próprios, não é dificil perceber que Fichte e Schelling se encontram na mesma posição teórica no que tange à concepção do Direito e da Ética.

104 Fichte, Grundlage des Naturrechts, § 4, Corollaria: 2), 54.

105 Ibidem, \$§ 13 e 14. 
$\mathrm{Na}$ medida em que este trabalho, como um dos seus resuitados, mostrou, a partir das concepções da coerção em Kant e Schelling, dois modelos de compreensão da relação entre Direito e Moral - um modelo, engiobando Kant e Hegel, procurando construir mediações entre ambas esferas; outro modelo, procurando fundar a racionalidade do Direito independente da racionalidade da Moral, no caso de Schelling e Fichte -, ele também nos ajuda entender a continuação desta discussão neste final de século XX, tal como esta discussão é levada a cabo na crítica de Habermas a Weber.

\section{3 - Weber e Habermas}

Como o próprio Habermas no prefácio de seu livro Facticidade e Validez (19942a.) confessa, ela é um herdeiro da tradiçăo kantiana, ao mesmo tempo em que, em sua teoria discursiva acerca do Direito e do Estado de direito democrático, afirma raramente referir-se a Hegel, já que este oferece "critérios inalcançáveis" ${ }^{106} \mathrm{Em}$ um trabalho anterior, no entanto, Habermas já havia afirmado que a ética do discurso pretendia resolver "esta intuição fundamental" de Hegel - a saber, mediatizar os direitos do individuo com o bem da comunidade - com a ajuda de um instrumentáno teórico kantiano. ${ }^{107}$ No entanto, năo são apenas estas referências externas que indicam a continuação por parte de Habermas, naturalmente em um contexto filosófico e histórico diferentes, das intuições fundamentais de Kant e desenvolvidas, posteriormente, por Hegel, mas também e, principalmente, a tese que articula sua crítica a Weber.

Por seu turno, Weber assume uma posição teórica que é a continuação das teses de Schelling e Fichte, naturalmente com um outro instrumental teórico, embora, tanto quanto eu saiba, não haja uma referência clara e explícita de Weber a esta filiação teónica. Ao que tudo indica, Schelling, Fichte e Weber parecem participar de uma mesmo Zeitgeist, o qual eles, de acordo com seus respectivos aparatos teónicos, souberam expressar. ${ }^{108}$

No contexto de modemização e racionalização das sociedades ocidentais analisadas por Weber, Habermas identifica o que ele considera uma unilateralidade no modo como Weber aborda o Direito modemo: a redução da racionalidade do Direito à racionalidade de tipo instrumental ${ }^{109}$. Este tipo de redução levado a cabo por Weber acarreta 1) a sua tese de que a legitimidade do poder é alcançada mediante a legalidade e 2) a recusa e critica do que ele denominava moralização ou materialização do Direito.

Weber defende a tese de que, nos estados ocidentais modernos, a legitimidade é conseguida através da legalidade, i. e., o poder político é reconhecido, posto que ele está baseado em uma ordenação juridica, estabelecendo a competência das ações dos governantes e dos governados. Há, portanto, um estatuto jurídico,

\footnotetext{
108 Habermas, Faktizität und Geltung, 9.

107 Habermas, Moralität und Sittlichkeit, 22.

108 Sobre a posição de Weber. v. Weber, Rechtssoziologie e o artigo citado na nota de pé de página número 1.

109 Habermas, Theorie des kommunikativen Handelns I, 352s.
} 
obtido mediante um acordo racionalmente produzido, estabelecendo as esferas legítimas de ação dos membros da sociedađe. A legalidade assim posta propicia as condiçōes adequadas às sociedades ocidentais modernas para o exercício legitimo e legitimado do poder. Uma vez que o mando politico năo está mais calcado na fé nas tradiçöes, no carisma do chefe politico ou em instâncias mítico-religiosas, entāo é a própria racionalidade imanente ao Direito aquilo que confere ao exercício do poder políticp a sua legitimidade: "legitimidade através da legalidade". ${ }^{110}$ Justamente a redução weberiana da racionalidade do Direito à dimensâo técnicoinstrumental mostra como o Direito pode ser um instrumento valioso, extremamente adequado e adaptado à organização das ações politicas, bem como ele o é também das açōes econômicas, ao mesmo tempo que concede a estas ações a sua aceitabilidade ou inaceitabilidade perante os membros da sociedade. Assim sendo, a incorporaçăo da racionalidade instrumental por parte da esfera jurídica torna-se um elemento fundamental, para que o poder político legítimo seja mediatizado pela legalidade do seu exercício.

Ora, a racionalidade própria ao sistema jurídico é formal, abstrata e universal, năo admitindo, portanto, a ingerência de postulados morais. Justamente o acolhimento de tais postulados pelo Direito, implicaria uma "materialiazação" ou "moralizaçåa" do mesmo, constituindo, com isto, um perigo não só para o Direito, como também para o tipo de legitimidade desenvolvido nas modernas sociedades industriais ocidentais. Uma tal moralização não só colocaria em risco a eficácia do aparato jurídico, na medida em que imperativos morais fossem assumidos pelo discurso jurídico, bem como levaria à erosão a legitimidade do poder nas sociedades industriais ocidentais, visto que a legalidade do poder estaria contaminada com pressupostos morais estranhos à lógica do poder legitimado por um estatuto jurídico racionalmente acordado. Em virtude disto, a legitimação do poder poderia recair em suas formas tradicionais.

Aos olhos de Habermas, Weber, em virtude desta critica à materializaçăo ou moralização do Direito, quer limitar a racionalidade do Direito a uma perspectiva meramente cognitivo-instrumenal, impedindo-o de abrir-se à resolução discursiva de pretensões à correção normativa (normative Richtigkeit)."11 "Ele [Weber, acréscimo de LAV] limita positivisticamente o conceito de Direito, de tal forma que ele pode negligenciar para a racionalização do Direito o aspecto prático-moral (princípio de fundamentação) e precisa levar em consideraçăo apenas o aspecto cognitivo-instrumental (princípio de estatuto)". ${ }^{112}$ Usando a terminologia até então empregada neste texto, Weber desloca o Direito da esfera prático-moral, considerando como algo prejudicial à dinâmica do Direito a aproximação com postulados morais, para o âmbito prático-técnico como sinal do mais alto grau de evolução do Direito. A crítica de Habermas se dirige justamente contra este estreitamento da racionalidade do Direito, colocando-o, em virtude disto, pelo menos no que diz respeito às intenções teóricas, na mesma linha de Kant e Hegel.

${ }^{110}$ Habermas, Faktizitat und Geltung, 541-545; Habermas, Theorie des kommunikativen Handelns I, 358 ss.

111 Habermas, Faktizität und Geltung, 541-545; Habermas, Theorie des kommunikativen Handelns I, 361 ss.

112 Habermas, Theorie des kommunikativen Handelns I, 362. 
Năo é meu interesse discutir a complexidade da argumentação habermasiana, a pertinência desta argumentaçăo e, finalmente, cotejá-la com possiveis ganhos e perdas frente as teses de Kant e Hegel. Neste contexto, quero apenas referir as sendas teóricas que estes dois grupos de pensadores trilham.

A argumentação habermasiana se concentra neste núcleo temático: as qualidades formais do Direito - a saber, "a sistematizaçăo do corpus jurídico, a forma da lei abstrata e universal e o procedimento limitando $o$ ato judicativo de juizes $e$ funcionários públicos", às quais correspondem, respectivamente, a "racionalidade científica" (wissenschaftliche Rationalität), a "racionalidade dirigida a fins" (Zweckrationalität) e a racionalidade de regras (Regelrationalität) ${ }^{113}$ - não garantem exclusivamente a legitimidade da legalidade. Uma tal legitimidade não pode prescindir de "uma relação interna entre Direito e Moral","14 na qual não haja somente uma complementação (Ergänzung), mas também um cruzamento (Verschränkung) entre Direito e Moral, ${ }^{115}$ sem que simultaneamente as suas diferenças sejam apagadas e sem que o Direito seja fundamentado pela Moral. Neste sentido, ele desenvolve, em um outro contexto histórico e filosófico, aquela mediaçăo entre as esferas éticas e jurídicas, já empreendida por Kant e Hegel. Com efeito, na perspectiva kantiana, a diferença entre a legislação juridica e ética diz respeito à ligaçăo entre o momento subjetivo ou motivacional da ação e o momento objetivo ou universal da lei e não propriamente às obrigações estabelecidas por ambas legislações. Assim sendo, uma obrigação jurídica pode tornar-se uma obrigaçăo ética, caso o elemento motivador (Triebfeder) da açāo seja a "idéia da obrigaçăo" mesma a ser realizada. ${ }^{116}$ Hegel, por sua vez, caracteriza "a união entre direito e dever" como "a força interna dos estados", ao mesmo tempo em que interpreta Direito Abstrato, Moralidade e Eticidade como momentos especificos da mediaçăo entre direito e dever. ${ }^{117}$ Desta forma, as Linhas Fundamentais da Filosofia do Direito podem ser encaradas como se ocupando fundamentalmente com a construção da mediação interna entre Direito e Moral.

Para Habermas, esta mediação tem o seu lugar, na medida em que a Moralidade adquire um caráter puramente procedimental: "ela [Moralidade; acréscimo de LAV] se esvaziou de todos conteúdos normativos determinados e se elevou à condição de um procedimento de fundamentação e aplicação de possíveis conteúdos normativos. (...) Nos discursos jurídicos, o tratamento argumentativo de questões ético-práticas é como que domado por via da institucionalização jurídica". ${ }^{118}$

Esta mediação proposta por Habermas tem por objetivo uma formação argumentativa e democrática da vontade, de tal forma que, graças a esta "liberdade comunicativa"119 vivenciada neste tipo de formação, as vontades assim constituídas possam construir um estado de direito efetivamente democrático.

\footnotetext{
${ }^{113}$ Habermas, Faktizitāt und Geltung, 544ss.

114 Ibidem, 550.

115 Ibidem, 137 e 568.

116 Kant, Metaphysik der Sitten, Rechtsichre, B 16 ss.

${ }^{117}$ Hegel, Grundlinien der Philosophie des Rechts, § 155 e § 261 Anm.

118 Habermas, Faktizität und Geltung, 568.

119 Ibidern, 147.
} 
Em virtude disto, Habermas pensa ter -evitado aquela consequiência inaceitável oriunda da tese weberiana. Como vimos antes, e de forma mais explicita, em Schelling, o Direito assumia um caráter instrumental, tendo por fim efetivar a liberdade. Mas justamente enquanto interpretado nesta perspectiva técnicoinstrumental, a própria concepção schellinguiana se mostrava frágil e incapaz, a partir de uma perspectiva imanente à sua própria teoria do Direito, de denunciar o desvio do Direito para fins diferentes da efetivação da liberdade. Algo semelhante ocorre com a posição teórica defendida por Weber, a qual acaba por operar uma abordagem positivista do Direito: "Direito é justamente aquilo que o legislador político (seja ele legitimado democraticamente ou não) pōe como Direito, segundo um procedimento juridicamente institucionalizado". ${ }^{120}$ Tomado nesta perspectiva técnica e afastado de qualquer mediação interna com a Moral, o Direito assim compreendido apresenta uma validade bastante precária para a idéia do Estado democrático.

Penso que o caminho teórico percorrido por Kant, Hegel e Habermas, para além de suas enormes diferenças - o que tornaria bastante proveitoso um cotejo mais detalhado entre a filosofia transcendental kantiana, a filosofia dialética hegeliana e a racionalidade comunicativa habermasiana acerca das questões de filosofia prático-moral -, apresenta ganhos evidentes, comparado com o triunvirato filosófico constituido por Fichte, Schelling e Weber.

Em primeiro lugar, eles não concordam em restringir a racionalidade do $\mathrm{Di}$ reito à dimensão técnico-instrumental, prático-técnica. De fato, não trata-se de eliminar esta função também desempenhada pelo Direito. Afinal, os domínios politico e econômico utilizam-se amiúde deste papel funcional representado pelo Direito. Seria ingênuo não reconhecer isto. Seria, todavia, estreiteza teórica restringi-lo a esta tarefa de agilizar a realização de interesses politicos e econômicos. Acorrentado a esta tarefa, escaparia ao Direito refletir sobre as correção das normas com as quais ele lida, bem como ele se fecharia em uma atitude meramente reinstauradora e reprodutora, para falar como Habermas, dos subsistemas poder e dinheiro. A sua inserçăo no âmbito prático-moral capacita-o para um posicionamento critico frente a estes subsistemas.

Isto nos leva, em segundo lugar, à questâo da justiça, já que, entendido em sua dimensão estritamente instrumental, o Direito passa ao largo e torna-se indiferente a esta questäo, com a qual ele, porém, estava intimamente entrelaçado na aurora do pensamento jurídico ocidental. ${ }^{121}$ Se nos lembrarmos do esforço de Kant em justificar a coerçăo exercida contra a coerçāo à universalidade do Direito como algo justo, da necessidade da Moralidade auxiliar o Direito, tendo em vista a realização da justiça (Hegel), e se nos dermos conta que também Habermas vê na "referência à justiça" "o genuino caráter do Direito", 122 então não ẻ difícil perceber que a degradação do Direito à condição de meio de organização dos subsistemas poder e dinheiro oblitera ou torna extremamente penoso ao próprio Direito refletir sobre aquilo que ele deve promover.

120 Ibidem, 541; Grifo da autor, LAV.

121 V. a este respeito Vaz, Escritos de filosofia II, 135-138.

122 Habermas, Faktizitat und Geltung, 589. 
A consideraçâo meramente instrumental do Direito, em terceiro lugar, agudiza a vulnerabilidade do aparato juridico por parte dos mais diversos grupos sociais interessados em sua instrumentalizaçăo. Embora uma mediação entre as esferas moral e jurídica nâo possa evitar por si mesma a utilização do sistema juridico para objetivos totalmente alheios ao seu genuino caráter, ela, todavia, nos fornece critérios - sujeitos, por sua vez, a um constante aprimoramento - para avaliar a justeza do que é juridicamente estipulado. Neste sentido, a tentativa de articular a esfera moral com a juridica equipa o Direito com critérios de justiça universalmente validados e partilhados, aos quais ele deve servir, ao invés de interpretá-lo no estilo de uma técnica sujeita aos mais variados usos.

Por fim, as posiçōes esposadas por Kant, Hegel e Habermas procuram articular as questōes prático-morais com a esfera pública, retirando-as do seu nicho particular-subjetivista, ao qual elas såo relegadas em muitas teorias modernas e pós-modernas.

\section{Referências bibliográficas}

ARISTOTELIS. Ethica Nicomachea. Oxford, Oxford University Press, 1949.

— . "Analytica posteriora". In: Anstotelis. Analytica priora et posteriora. Oxford, Oxford Univer. sity Press, 1968.

BARTUSCHAT, W. Zur Deduktion des Rechts aus der Vernunft bei Kant und Fichte. In: KAHLO, M., WOLFF, E. e ZACZYK, R. (Orgs.) Fichtes Lehre vom Rechtsverhaltniss. Die Deduktion der \$\$ 1-4 der Grundlage des Naturrechts und ihre Stellung in der Rechtsphilosophie. Frankfurt/M: Vittorio Klostermann, 1992, 173-193.

FICHTE. J. Grundlage der gesamten Wissenschaftslehre. Berlin, Walter de Gruyter, 1971, (Vol. D).

- System der Sittenlehre nach den Prinzipion der Wissenschaftslehre. Berlin, Walter de Gruyter, 1971, (Vol. IV).

- Grundlage des Naturrechts nach den Prinzipien der Wissenschaftslehre. Berlin, Waiter de Gruyter, 1971, (Vol. III).

- System der Sittenlehre nach den Prinzipien der Wissenschaftslehre. Berlin, Waiter de Gruyter, 1971, (Vol. IV).

HABERMAS, J. Paktizität und Geltung. Beiträge zur Diskurstheorie des Rechts und des demokratischen Rechtsstaats. Frankfurt/m, Suhrkamp, 1994.

- Moralităt und Sittlichkeit. Treffen Hegels Binwànde gegen Kant auch auf die Diskursethik zu? In: Kuhlmann, W. (Bd.) Moralităt und Sittlichkeit. Frankfurt/M, Suhrkamp, 1986, 16-37.

- Theorie des kommunikativen Handelns. Handlungsrationalităt und gesellschaftliche Rationalisierung. Frankfurt/Main, Suhrkamp, 1992, 2 Vols.

HEGRL, G. Bnzyklopädie der philasophischen Wissenschaften im Grundrisse. 1830. Dritter Teil. Frankfurt/M, Suhrkamp, 1986.

- Grundilinien der Philasophie des Rechts. Frankfurt/M, Suhrkamp, 1986.

HOLLERBACH, A. Schellings Rechts- und Staatsbegrif in den Jahren 1796-1800. In: Frank, M. e Kurz, G. (Orgs). Materialien zu Schellings philosaphischen Anfaingen. Frankfurt/M, Surhkamp, 1975., 307324.

KANT, I. Grundlegung zur Metaphysik der Sitten. Darmstadt, Wissenschaftliche Buchgesellschaft, $1983,(V .6)$.

- Kritik der reinen Vernunft. Darmstadt, Wissenschaftliche Buchgesellschaft, 1983, (VV. 3 e 4).

- Knitik der praktischen Vernunft. Darmstadt, Wissenschaftliche Buchgesellschaft, 1983, (V. 6).

— . Die Metaphysik der Sitten. Darmstadt, Wissenschaftliche Buchgesellschaft, 1983, (V. 7).

— . Kritik der Urteilskraft. Darmstadt, Wissenschaftliche Buchgesellschaft, 1983, (V. 8).

- Zum ewigen Fhioden. Ein philosophischer Entwurf. Darmstadt, Wissenschaftliche Buchgesellschaft, 1983, (V. 9). 
KÖHLER, M. Zur Begründung des Rechtszwangs im Anschluss an Kant und Fichte. In: Kahlo, M. Wolf, B. e Zaczyk, R. (Orgs.) Flchtes Lehre vom Rechtsverhältniss. Die Deduktion der $\$ \S 1-4$ det Grundlage des Naturrechts und fhre Stellung in der Rechtsphilosophie. Frankfurt/M: Vittorio Klostermann, 1992, 93-125.

RIVELAYGUE, J. Schelling et les apories du droit. In: Cahiers de philosophie politique. No. 1, Bruxelas, Ousia, 1983, 13-62.

SCHBLLING, Friedrich Wilheim Joseph. Neue Deduktion des Naturrechts: In: Schelling, Friedrich Wilhelm Joseph. Historisch-Kritische Ausgabe. Im Auftrag der Schelling-Komission der Bayerischen Akdemie der Wissenschaften. Buchner, H., Jacobs, W. und Pieper, A. (Bds.). Stuttgart, Frommann-Holzboog, 1982, Werke 3.

- System des transzendentalen Idealismus. Darmstadt, Wissenschaftliche Buchgesellschaft, (Schriften von 1799 - 1801).

STRANGAS, J. Kritik der Kantischen Rechtsphilosophie. Colónia, Böhlau, 1988.

VAZ, Henrique. Escritos de Filosofia II. Ética e cultura. Sảo Paulo, Loyola, 1988.

VIEIRA, L. Freiheit als Kultus. Aporien und Grenzen der Auffassung der menschlichen Freiheit bei Hegel. Würzburg, Königshausen \& Neumann, 1996.

- A herança kantiana na concepçâo hegeliana do direito e da moral. In: Sintese Nova Fase (Vol. 27), no. 77, Abril-Junho 1997, 163-179.

WBBER, M. Rechtssoziologie (Wirtschaft und Recht). In: Idem. Grundriss der Sozialokonomik. III. Abteiluung. Wirtschaft und Gesellschaft. Tubingen, C. B. Mohr, 1947. 